\title{
Methanolic Extract of Angelica glauca Edgew Root and Stem: A Possible Component of Herbal Medicines against Respiratory Infections
}

\author{
Prashant Arya, Jagat Prakash Mehta, Vineet Kumar Maurya* \\ Department of Botany and Microbiology, HNB Garhwal University, Srinagar, Uttarakhand, INDIA.
}

\begin{abstract}
Plants are identified to produce a variety of compounds to protect themselves against a diversity of pathogens. This study assessed the antibacterial, antioxidant potential and phytochemical screening of medicinal plant Angelica glauca (Choru) root and stem extracts against respiratory tract pathogens i.e., Staphylococcus aureus MTCC 1144, Streptococcus pneumoniae MTCC 655, Streptococcus pyogenes MTCC 442, Pseudomonas aeruginosa MTCC 2474 and Klebsiella pneumoniae MTCC 4030. The plant material was collected from Tungnath $3,800 \mathrm{~m}$ amsl of Garhwal Himalaya. Root and stem of the plants were washed, shade dried, grinded into fine powder and extracted in the organic solvents of different polarity (petroleum ether, chloroform, methanol and water). Antibacterial activities of prepared extracts were assayed using agar well diffusion and two-fold serial dilution method of MIC determination. Antioxidant potential was determined using DPPH assay and phytochemical analysis was performed using qualitative methods for different phytochemicals. Experimental outcomes revealed maximum antibacterial and antioxidant activity of methanol extract; also the maximum groups of phytochemicals were present in the methanolic extract. The methanol extract produced ZOls of $11.0 \pm 0.54 \mathrm{~mm}$ to $30.3 \pm 1.58 \mathrm{~mm}$ diameters and MICs ranges were recorded between $3.12 \mathrm{mg} / \mathrm{ml}$ to $25 \mathrm{mg} / \mathrm{ml}$ against all the tested bacteria. Alkaloids, flavonoids, glycosides, tannins, steroids and saponins were present in the extracts of $A$. glauca. This study favors a good response towards using $A$. glauca as natural antioxidant in herbal medicines, either in pure form or as supplement with other herbal formulations already available in the market, to enhance their potential against respiratory tract diseases. In the present COVID-19 pandemic situation, use of $A$. glauca can be beneficial, as it's methanolic extract showed promising antibacterial activity against bacterial pathogens of human respiratory tract.
\end{abstract}

Key words: Angelica glauca, Antibacterial, Two-fold serial dilution, Natural antioxidant, Phytomedicine, Respiratory tract pathogens, DPPH, COVID-19.

\section{INTRODUCTION}

Plants resources have played a pivotal role in development and sustaining human life since the inception of human civilization, and will remain indispensable part of it. Besides the three basic needs of human life i.e., food, fiber and shelter, another most important aspect of human's life i.e., health is also dependent on plant resources to great extent. Plants possess remarkable therapeutic properties and have remained important constituent of nutraceuticals, Ayurvedic, Unani, homeopathic, herbal and allopathic medicines. One-quarter of all drugs come either directly or as derivative from plants. Plant derived remedies are traditionally being used in fighting against various nutrient deficiency generated, physiological and pathogen based diseases, and microbial disease are not the exceptions of it. ${ }^{1,2}$ In last few decades, plant derived extracts and bio-active phytochemicals have been reported to play a crucial role in development new drug. ${ }^{3}$ All five parts i.e., 'Panchaang' (root, stem, leaves, flowers
Submission Date: 08-12-2020; Revision Date: 03-03-2021; Accepted Date: 03-05-2021

DOI: 10.5530/ijper.55.2s.127 Correspondence: Dr. Vineet Kumar Maurya Department of Botany and Microbiology, HNB Garhwal University, Srinagar-249161, Uttarakhand, INDIA.

Phone: +91-9411072113

Email id: vineetkm2000@ gmail.com

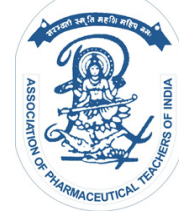

www.ijper.org 
and seeds) either individually or in combinations are useful for therapeutic purposes. Plants are important source of various secondary metabolites like alkaloids, tannins, flavonoids, steroids, phenolics etc. which show distinct bioactive properties including antimicrobial activities that form the basis for applications of plants in pharmaceuticals. ${ }^{4-6}$ Phenolics contained in essential oils are well recognized as potential insecticidal agents. ${ }^{7,8}$ Reactive Oxygen Species (ROS) such as superoxide anion, hydroxyl radical and hydrogen peroxide, play the key role in the development of various illnesses such as arthritis, asthma, bronchitis, dementia, mongolism, carcinoma and Parkinson's disease in human. Plants provide a good hope in alleviating ROS generated disease because of containing natural antioxidant compounds which save cells from the harmful effects of ROS and reactive nitrogen species (RNS). Clinical data show that antibiotics are the main weapon against microbial (bacterial and fungal) infections but antibiotics misusage have given rise to the problem of presence and spread of multi-drug resistance among various pathogenic micro-organisms, ${ }^{9}$ and plants are expected to provide new therapeutic molecules to counter drug resistant microbes.

Respiratory tract infections are a major cause of sickness and death. ${ }^{10}$ Respiratory conditions such as allergies, asthma and chronic obstructive pulmonary disease (COPD) are the world's main public health concerns. Recent pandemic of COVID-19 is also a respiratory tract infection, but caused by virus. ${ }^{11}$ The micro-organisms namely Streptococcus pneumoniae, Klebsiella pneumoniae, Staphylococcus aureus, Haemophilus influenzae, Pseudomonas aeruginosa, Acinetobacter baumannii and Stenotrophomonas maltophilia are the most common causative agents of such types of infections. ${ }^{12}$ Streptococcus pyogenes, Streptococcus pneumoniae, Klebsiella pneumoniae, Staphylococcus aureus and Pseudomonas aeruginosa, used in this study, are opportunistic pathogens which causes mild to severe infections. MTCC strains of these pathogens; Streptococcus pyogenes (MTCC 442), ${ }^{13,14}$ Streptococcus pneumoniae (MTCC655), ${ }_{14}^{14}$ Klebsiella pneumoniae (MTCC 4030), ${ }^{15}$ Staphylococcus aureus (MTCC 1144) $)^{16,17}$ and Pseudomonas aeruginosa (MTCC 2474) $)^{14,18}$ have been used as respiratory tract, urinary tract pathogens by various research groups for anti-bacterial assays.

Genus Angelica of the family Apiaceae is globally recognized for its uses in traditional and modern medicine systems. 110-115 species of Angelica are world reported, and 87 species of them occur in Asia. ${ }^{19}$ Angelica glauca edgew, A. archangelica L. and A. nubigena $\mathrm{Cl}$. have been reported from the Indian Himalaya region. ${ }^{20}$ Out of them Angelica glauca Edgew (locally called as Choru- vernacular name-
Choru; Sanskrti name- Gandrayan; English namesmooth Angelica), is widely distributed in the Himalayan regions of Uttarakhand, Jammu and Kashmir and Himachal Pradesh along amsl of 2000 to 3,800m. ${ }^{21}$

A. glauca is well known for its aromatic and therapeutic values. It has been grouped under 'Chandanadi varg' by Shodala nighantu which also indicates presence of volatile oils and flavonoids in it. In Charak Samhita $A$. glauca has been classified under 'Sanjasthapana varg', which means for bringing consciousness to fainted persons. Flowering period started from July to August and fruiting period is September to October. ${ }^{22}$ Several Angelica species have been used in home-grown system of medicine as antiinflammatory in stomachache, in skin diseases and as a diuretic. A. glanca leaves are used against fever, jaundice and the paste of leaves is useful in skin allergy. ${ }^{23}$ Roots and stem of $A$. glauca are used for constipation, urinary disorders, rheumatism, bronchitis, cough, cold and asthma ${ }^{21,22}$ and considered effective in cardiac disease. Local communities use its roots and stem as a spice especially for seasoning curry. ${ }^{24}$ Pharmacological studies revealed the role of $A$. glauca in Unani and ayurvedic drugs against common cold, asthma, cough and other respiratory and stomach infection. ${ }^{22}$

Presence of essential oil in A. glauca has attracted many phytochemical and antibacterial studies on it. $\mathrm{Z}$ and E-ligustilide, $\mathrm{Z}$ and E-butylidene phthalide, caryophyllene oxide, thujene, terpinene, nerolidol, bisabolene, 6 types of coumurins and 23 other compounds have been isolated from essential oil of Angelica species. ${ }^{23,25-28}$ Different biological activities like anti-oxidant, anti-seizure, cytotoxicity, Anti-aflatoxigenic, nicotine sensitizaiton, anti-inflammatory, mosquito repellent etc., have been reported in different species of Angelica. ${ }^{28}$ Root extract of $A$. archangelica L. showed potent antimicrobial activities against four fungal and five bacterial pathogens. ${ }^{29} A$. sinensis and $A$. daburica were found active against Staphylococcus aureus, Staphylococcus chromogenes, and Streptococcus uberis. ${ }^{30}$ Essential oil of $A$. archangelica was also found effective in agricultural and food items preservations. ${ }^{31}$ Antibacterial activities of $A$. glauca whole plant extract have been reported against bacteria (Staphylococcus aureus, Bacillus subtilis, Escherichia coli, and Pasteurella multocida) and fungi (Candida albicans, Microsporum canis, Aspergillus flavus and Fusarium solani), ${ }^{25,26}$ which were comparable to Amoxicillin and Flumequinene, respectively. Essential oil of A. galuca was effective in treating histamine and ovalbumin induced allergic asthama in guinea pigs and mice. ${ }^{32}$ Three antimicrobial peptides (AMPs) (a-phellandrene, transcarveol, b-pinene caryophyllene) were isolated from dried aerial part of $A$. glauca which were found very 
effective against $K$. pneumoniae, $P$. aeruginosa. ${ }^{23}$ AMPs have their unique mechanism of antibacterial action and could be effective against drug resistant bacteria. ${ }^{33}$

Despite of reports on use of $A$. glanca in local herbal medicines, its use in herbal formulations for respiratory ailments, available in the market, is not observed. Even the recently proposed 'Arogya-Kashayam-20' an Ayurvedic medicine for asymptomatic patients of COVID-19 also don't have $A$. glauca. Several reports on medicinal properties of essential oil, obtained from $A$. glanca are available. The present work was based on antioxidant potential and antibacterial properties of $A$. glauca against respiratory tract pathogens, along with qualitative estimations of various phytochemicals present in it, to establish its further medicinal applications.

\section{MATERIALS AND METHODS}

\section{Plant Material}

The healthy plants of $A$. glauca were collected from Tungnath (District Rudraprayag, Uttarakhand), on the way of Chandrashila, at $3,800 \mathrm{~m}$ amsl (Figure 1). Plant identification was performed by authentication of collected specimens at Garhwal University Herbarium (GUH), H. N. B. Garhwal University Srinagar (Garhwal) and the same voucher was deposited to the herbarium with 'Accession No. GUH-20748'. Root and stem were properly washed under running water, shade dried and grinded together into fine powder for further use.

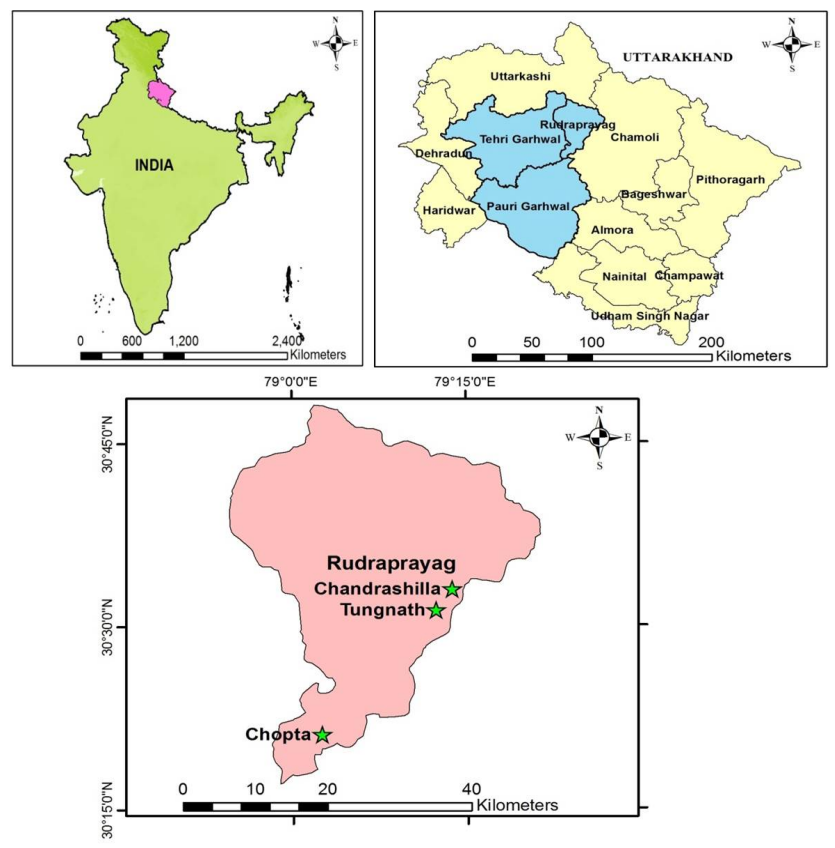

Figure 1: Maps showing Collection site of Angelica glauca.

\section{Preparation of Extract}

Four different solvents i.e., Petroleum Ether (PET), Chloroform (CHF), methanol $(\mathrm{MeOH})$ and water, were used for preparation of $A$. glauca extracts. Extracts were prepared by soaking $100 \mathrm{~g}$ of powdered plant material in $300 \mathrm{ml}$ of each solvent. Soaking plant material along with the solvent, was filled in Soxhlet apparatus and extracted by successive method for $72 \mathrm{~h}^{34}$ The recovered plant extracts were passed through Whatman No. 1 filter to remove insoluble materials and the filtrate was concentrated using rotatory vacuum evaporator to obtain thick gummy extract. For antibacterial assays, the extracts were dissolved in 'dimethyl sulfoxide' (DMSO) to achieve $200 \mathrm{mg} / \mathrm{ml}$ concentration.

\section{Test Micro-organisms}

Following bacterial pathogens causing human respiratory tract infections were used in present study: Staphylococcus aureus (MTCC 1144), Streptococcus pneumoniae (MTCC 655), Streptococcus pyogenes (MTCC 442), Psendomonas aeruginosa (MTCC 2474) and Klebsiella pneumoniae (MTCC 4030). These bacterial strains were purchased from 'Institute of Microbial Technology (CSIR-IMTECH), Chandigarh. After procurement the bacterial strains were cultured and maintained using standard bacteriological protocols described by Chandra, et al. ${ }^{35}$

\section{Inoculum Preparation}

Standard cultures were maintained on agar-slant at $4^{\circ} \mathrm{C}$. Active experimental cultures were prepared by adding a loopful of bacterial cells from standard cultures to Mueller-Hinton broth (MHB) tubes, followed by incubation at $37^{\circ} \mathrm{C}$ for $24 \mathrm{hrs}$.

\section{Antibacterial testing}

Antibacterial activity of 'root and stem' extract of different solvents was determined by agar well-diffusion method..$^{34} 100 \mu$ of $12-16$ hrs grown cultures of bacteria were mixed with $20 \mathrm{ml}$ of molten Mueller Hinton Agar (MHA) (Medium no. 173, HiMedia Pvt. Ltd., Mumbai, India) and poured into pre-sterilized petri plates. Wells were punched in solidified MHA media using sterile cork borer (6.0 mm diameter) and filled with of $45 \mu \mathrm{l}$ of extracts solutions (dissolved in DMSO having final concentration of $200 \mathrm{mg} / \mathrm{ml}$ ). Erythromycin, a broadspectrum antibiotic and pure DMSO were used as positive and negative controls, respectively. Plates were incubated at $37^{\circ} \mathrm{C}$ for $24 \mathrm{hrs}$, and the diameter of the clear zone (Zone of Inhibition, ZOI), appearing around each well was measured. Experiments were performed in triplicates and mean values with \pm SD were recorded. The antibacterial activity was interpreted from the ZOIs, measured in nearest millimeter $(\mathrm{mm})$. 


\section{Determination of Minimum Inhibitory Concentrations (MICs)}

Two-fold serial dilution method was used for determining the minimum inhibitory concentrations (MICs) against selected bacterial species, ${ }^{35,36}$ with slight modifications. Six serial dilutions of each extract $(50,25,12.5,6.25$, 3.12 and $1.56 \mathrm{mg} / \mathrm{ml}$ ) were used for MIC determination. Tube containing equal volume of normal saline in place of bacterial inoculum was used as negative control. All tubes were incubated for $24 \mathrm{hrs}$ at $37^{\circ} \mathrm{C}$. The lowest concentration of the extract in the tube showing no visible growth (turbidity) was considered as MIC of that extract.

\section{Phytochemical screening}

The primary phytochemical analyses were performed for qualitative estimation of various phytochemicals present in root and stem extracts of $A$. glauca.

\section{Test for alkaloids}

Solvent free extract was dissolved in aqueous acidic solution (Hydrochloric acid or Acetic acid) and filtered. One or two drops of Mayer's reagent were added slowly by the wall of test-tube to $5 \mathrm{ml}$ of filtrate. Formation of white creamy precipitate was a positive indication for presence of alkaloids in the extract. ${ }^{37}$

\section{Test for flavonoids}

Alkaline reagent test: Extract was dissolved in methanol and $1 \mathrm{~N} \mathrm{NaOH}$ solution was added to it. Appearance of intense yellow colour, which disappears upon adding an acid to it, confirms the presence of flavonoids in the sample. ${ }^{38-41}$

Shinoda test: Small amount of magnesium and concentrated hydrochloric acid were added to the plant extract. The appearance of pink color after few minutes indicates the presence of flavonoids in the extract. ${ }^{40,41}$

\section{Test for glycosides}

Plant extract was dissolved in water, heated and filtered. The appearance of brick red color, upon adding $0.2 \mathrm{ml}$ of Fehling solutions to the $5.0 \mathrm{ml}$ of filtrate, confirmed the presence of glycosides in it. If instead of water, diluted $\mathrm{H}_{2} \mathrm{SO}_{4}$ is added and process is repeated, then appearance of a thicker precipitate compared to previous one, further confirms the presence of glycosides in it. ${ }^{42}$

\section{Test for Steroids}

The extract was dissolved in chloroform. Appearance of green color upon adding few drops of conc. $\mathrm{H}_{2} \mathrm{SO}_{4}$ and acetic anhydride to it is the positive indicator for presence of steroids in the sample. ${ }^{43}$

\section{Test for reducing Sugars}

The extract was dissolved in water and 1:1 mixture of Fehling solutions A and B were added to it. Appearance of brick red colored precipitate upon heating indicated the presence of aldolase (reducing) sugars in the sample.

\section{Test for Saponins}

$20 \mathrm{mg}$ of extract was boiled and cooled with $10 \mathrm{ml}$ of water in a test tube for two minutes. The mixture was shaken vigorously, and left for $3 \mathrm{~min}$. Formation of 1 $\mathrm{cm}$ thick foam layer indicates for presence of saponins in the sample. ${ }^{44}$

\section{Test for Tannins}

Plant extract was dissolved in water and 10\% Ferric chloride was added to it. Presence of blue green color indicates the presence of tannins in the sample.

\section{Evaluation of Antioxidant Potential using DPPH method}

One $\mathrm{ml}$ methanol solution of extract was mixed with $3 \mathrm{ml}$ solution of $2 \times 10^{-4} \mathrm{~mol} / \mathrm{L}$ ethanolic 2,2-diphenyl1-picrylhydrazyl (DPPH) solution and final volume was maintained to $10 \mathrm{ml}$ using methanol. The mixture was vigorously shaken, and absorbance was instantly assessed at $517 \mathrm{~nm}$. The absorbance decrease was estimated at 15 and $30 \mathrm{~min}$ before the absorbance reached a steady state (after almost $30 \mathrm{~min}$ ). Reduction in colour of DPPH was indication of positive indication of antioxidant activity in plant extracts and degree of colour reduction was directly proportional to antioxidant activity. The sample without plant extract but pure solvent and DPPH was used as blank. ${ }^{45}$

\section{RESULTS AND DISCUSSION}

\section{Antibacterial activities of A. glauca 'root and stem' extracts}

The essential oil obtained from different species of Angelica had been reported to show potent antibacterial and antifungal activities. Essential oil from $A$. archangelica roots was found effective in controlling the growth of bacteria (Clostridium difficile, Clostridium perfringens, Enterococcus faecalis, Eubacterium limosum and Peptostreptococcus anaerobius) and fungi (Fusarium genus, Botrytis cinerea, Alternaria solani, and Candida albicans). ${ }^{29,46}$ Growth of S. aureus, Staphylococcus chromogenes, and Streptococcus uberis was controlled by essential oil obtained from roots of $A$. sinensis and $A$. daburica. ${ }^{30}$ Besides antibacterial activity, the essential oil obtained from roots of $A$. archangelica, $A$. pubescentis Maxim and $A$. koreana Maxim. showed potent antifungal activities. ${ }^{47,48}$ 
In present study the 'root and stem' extract of $A$. glauca exhibited potential antibacterial activity against tested bacterial pathogens, the results of antibacterial activities of 'root and stem' extracts of $A$. glauca, in different organic solvents, are shown in Table $1 . \mathrm{MeOH}$ extract of $A$. glanca exhibited maximum antibacterial activity compared to aqueous, $\mathrm{CHF}$ and PET extracts. $\mathrm{MeOH}$ extract showed strongest activity against $S$.aureus $(30.3 \pm 1.58 \mathrm{~mm})$, followed by $S$. pyogenes $(22.3 \pm 0.42 \mathrm{~mm})$, $P$. aeruginosa $(22.3 \pm 0.38 \mathrm{~mm}), S$. pneumoniae $(21.3 \pm 1.28$ $\mathrm{mm})$ and $K$. pneumoniae $(19.0 \pm 0.54 \mathrm{~mm})$. Aqueous extract showed minimum inhibition compared to other extracts. Aqueous extract showed maximum activity against $S$.aureus $(19.3 \pm 1.73 \mathrm{~mm})$ followed by $P$. aeruginosa $(15.6 \pm 0.78 \mathrm{~mm}), S$. pneumoniae $(14.6 \pm 0.23 \mathrm{~mm}), S$. pyrogens $(11.0 \pm 0.54 \mathrm{~mm})$ and $K$. pneumoniae $(11.6 \pm 0.47$ $\mathrm{mm}$ ). Maximum and minimum inhibition by $\mathrm{CHF}$ extract was found against $S$. aureus $(24.3 \pm 0.25 \mathrm{~mm})$ and K. pneumoniae $(15.6 \pm 0.25 \mathrm{~mm})$. The PET extract showed maximum activity against $S$. aureus $(23.6 \pm 0.38 \mathrm{~mm})$, and least activity against $K$. pneumoniae $(16.6 \pm 0.97 \mathrm{~mm})$.

There are number of reports on antibacterial potential of medicinal plants extracts against the human bacterial pathogens. These activities indicate the presence of certain metabolites having wide spectrum of antibiotic activities. A. glauca has well known medicinal and aromatic values; the roots of $A$. glauca contains valeric acid, angelic acid and angelisine resin are valued in treatment of cough, cold, asthma and inflammation. ${ }^{26,49}$ Irshal et al. (2011) reported that essential oil of $A$. glauca (whole plant) showed antimicrobial action against Staphylococcus aureus, Bacillus subtilis, Escherichia coli and Pasteurell amultocida and found that the essential oil was most effective against $E$. coli and $S$. aureus. Present work demonstrated that all the extracts were also most effective against $S$. aureus. The whole plant essential oil also showed weak antibacterial activity against bifidobacteria and lactobacilli. The aqueous 'root and stem' extract of A. glauca showed antibacterial activity in the order Staphylococcus aureus $>$ Psendomonas aeruginosa $>$ Streptococcus pneumoniae $>$ Streptococcus pyogenes $\geq$
Klebsiella pneumoniae. Han and Guo assayed antibacterial activity of Angelica sinensis roots against E. coli, S. aureus, Monilia albicans, Shigella and Salmonella typhimurium but no significant activity was reported by them. ${ }^{50}$ Almost similar to their finding the least antibacterial activity of aqueous extract was reported in present work. Antibacterial activity of different extracts of $A$. glauca was compared with standard antibiotics (Erythromycin). In case of $S$. aureus crude $\mathrm{MeOH}$ extract of $A$. glauca produced $30.3 \pm 1.58 \mathrm{~mm} \mathrm{ZOI}$, equivalent to the commercial use broad spectrum antibiotic erythromycin $30.3 \pm 0.87 \mathrm{~mm}$ (Table 1). But in other cases, the positive control (erythromycin) was found to be slightly more effective than extracts of $A$. glauca. Erythromycin is an antimicrobial macrolide with broad spectrum design. It has better and wide spectrum of action against respiratory tract infections particularly for atypical species like mycoplasma and legionellosis. The MICs result showed the range of MIC values from 3.12 to 25 $\mathrm{mg} / \mathrm{ml}$ (Figure 2). The lowest MIC of $\mathrm{MeOH}$ extract of A. glauca was observed against $S$. pneumoniae and $S$. aureus $(3.12 \mathrm{mg} / \mathrm{ml})$. MIC value of the same extract against S. pyogenes, P. aeruginosa and K. pneumonia were $6.25 \mathrm{mg} /$ $\mathrm{ml}, 12.5 \mathrm{mg} / \mathrm{ml}$ and $25 \mathrm{mg} / \mathrm{ml}$, respectively. The MIC values of other extracts were not determined because

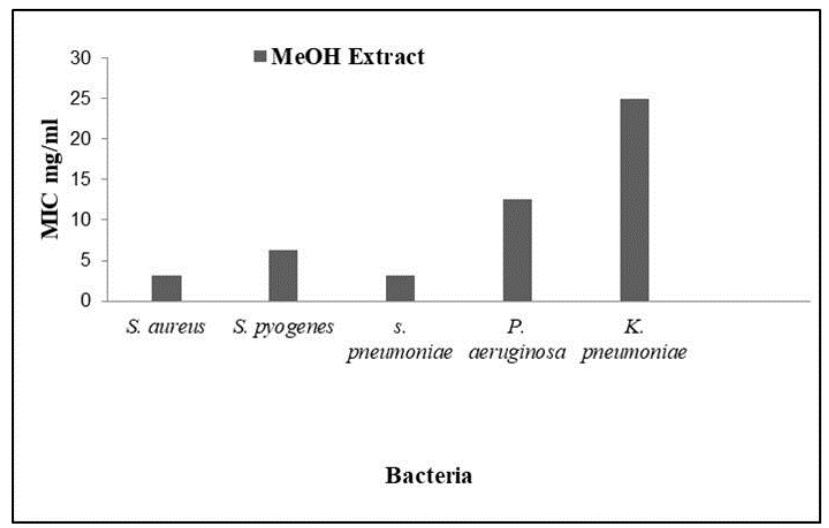

Figure 2: Minimum inhibitory concentrations (MICs) $\mathrm{mg} / \mathrm{ml}$ of methanol extract of A. glauca.

\begin{tabular}{|c|c|c|c|c|c|c|}
\hline \multirow[t]{2}{*}{ Micro-organism } & \multicolumn{4}{|c|}{ Inhibition zone diameter (mm) } & \multirow{2}{*}{$\begin{array}{c}\text { Positive control } \\
\text { Erythromycin }\end{array}$} & \multirow{2}{*}{$\begin{array}{c}\begin{array}{r}\text { Negative } \\
\text { Control }\end{array} \\
\text { DMSO }\end{array}$} \\
\hline & PET & $\mathrm{CHF}$ & $\mathrm{MeOH}$ & $\mathrm{H}_{2} \mathrm{O}$ & & \\
\hline Staphylococcus aureus & $23.6 \pm 0.38$ & $24.3 \pm 0.25$ & $30.3 \pm 1.58$ & $19.3 \pm 1.73$ & $30.3 \pm 0.87$ & 0 \\
\hline Streptococcus pyogenes & $19.0 \pm 0.57$ & $16.6 \pm 0.76$ & $22.3 \pm 0.42$ & $11.0 \pm 0.54$ & $24.6 \pm 0.76$ & 0 \\
\hline Streptococcus pneumoniae & $20.3 \pm 0.28$ & $15.6 \pm 0.50$ & $21.3 \pm 1.28$ & $14.6 \pm 0.23$ & $23.0 \pm 1.32$ & 0 \\
\hline Pseudomonas aeruginosa & $17.3 \pm 0.24$ & $19.6 \pm 0.56$ & $22.3 \pm 0.38$ & $15.6 \pm 0.78$ & $24.3 \pm 0.51$ & 0 \\
\hline Klebsiella pneumoniae & $16.6 \pm 0.97$ & $15.6 \pm 0.25$ & $19.0 \pm 0.54$ & $11.6 \pm 0.47$ & $21.6 \pm 0.76$ & 0 \\
\hline
\end{tabular}

Values of three replicates: Mean $\pm S D$; Cork borer diameter: $6 \mathrm{~mm}$. 
the ZOIs shown by them were smaller compared to $\mathrm{MeOH}$ extracts against all the tested pathogen under consideration.

The results of this study corroborated very well with studies by other research groups on $A$. glauca or other species of Angelica. The $\mathrm{MeOH}$ extract of $A$. glauca (Stem and Root) exhibited $30.3 \pm 1.58 \mathrm{~mm}$ ZOI against standard strains of $S$. aureus and its MIC was found $3.12 \mathrm{mg} / \mathrm{ml}$. The sensitivity of $S$. aureus, $S$. pyogenes, $P$. aeruginosa, $S$. pneumoniae and $K$. pneumoniae are quite remarkable. The involvement of these microorganisms in respiratory diseases is fairly notable and well known. S. pyogenes colonize the throat or skin and causes pharyngitis, impetigo, rheumatic fever, and acute glomerulonephritis. ${ }^{51} S$. pneumoniae causes mild respiratory tract mucosal infections such as otitis media and sinusitis. Sometime it may cause more severe diseases such as pneumonia, septicemia, and meningitis. ${ }^{52}$ Klebsiella pneumoniae is an opportunistic pathogen, which mostly affects immune-compromised patients and causes nosocomial urinary tract infections, pneumonia, septicemias, and soft tissue infections. It also causes life-threatening community-acquired infections, such as pyogenic liver abscess, meningitis, fasciitis, endophthalmitis and severe pneumonia. ${ }^{53} S$. aureus colonizes skin, but sometime causes different pyogenic and systemic infections. Most of $S$. aureus infections are not serious, but sometimes can be serious such as bloodstream infections, pneumonia, or bone and joint infections. ${ }^{54}$ P. aeruginosa is a nosocomial pathogen that affects immuno-compromised patients. It causes urinary tract infections, respiratory tract and other soft tissue infections..$^{55}$

\section{Antioxidant activity of A. glauca root and stem extracts}

The results of antioxidant activity assay showed the presence of natural antioxidants in 'root and stem' extract of $A$. glauca. At $100 \mu \mathrm{g} / \mathrm{ml}$ concentration the $\mathrm{MeOH}$, aqueous, $\mathrm{CHF}$ and PET showed $92.5 \%, 40 \%$, $80 \%$ and $30 \%$ reduction of $\mathrm{DPPH}$, while at $400 \mu \mathrm{g} / \mathrm{ml}$ aqueous extract reduced $95.81 \%$ of DPPH (Figure 3 to Figure 6). The potential to scavenge DPPH radical was measured for determining $\mathrm{IC}_{50}$ value which indicate the concentration required to inhibit $50 \%$ of $\mathrm{DPPH}$ free radicals. Lower values of $\mathrm{IC}_{50}$ indicate higher potency to scavenging DPPH free radicals of plants extract. $\mathrm{IC}_{50}$ value of the $\mathrm{MeOH}$ extract $(69.42 \mu \mathrm{g} / \mathrm{ml})$ was much lower in comparison to CHF extract $(100.71 \mu \mathrm{g} /$ $\mathrm{ml})$, PET extract $(261.35 \mu \mathrm{g} / \mathrm{ml})$ and aqueous extract $(231.65 \mu \mathrm{g} / \mathrm{ml})$ of $A$. glauca (Figure 7). In comparison to standard antioxidants like BHA, ascorbic acid and rutin,

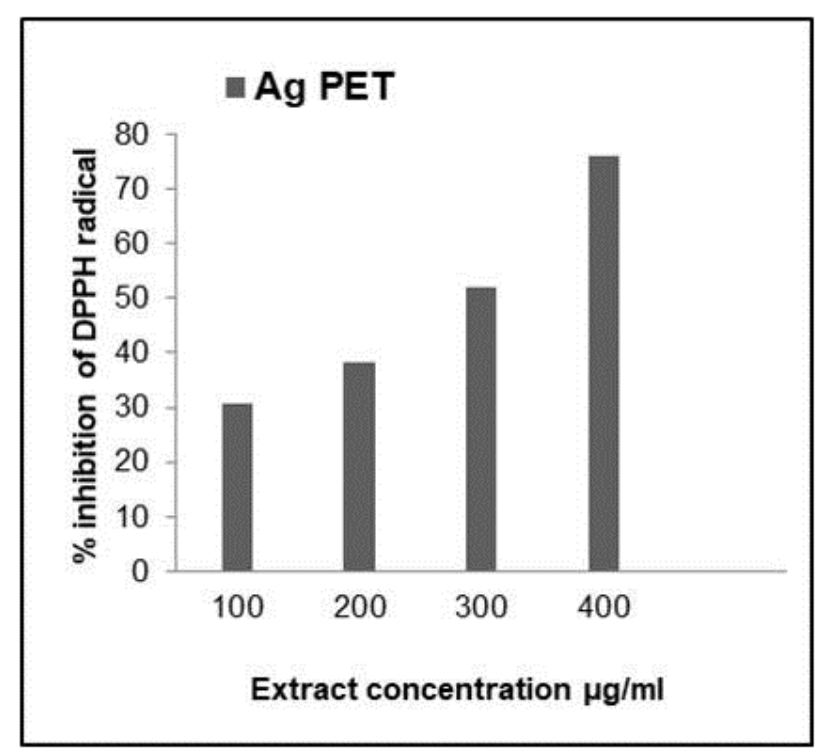

Figure 3: \% Inhibition of DPPH free radicals by A. glauca petroleum ether extract (Ag PET).

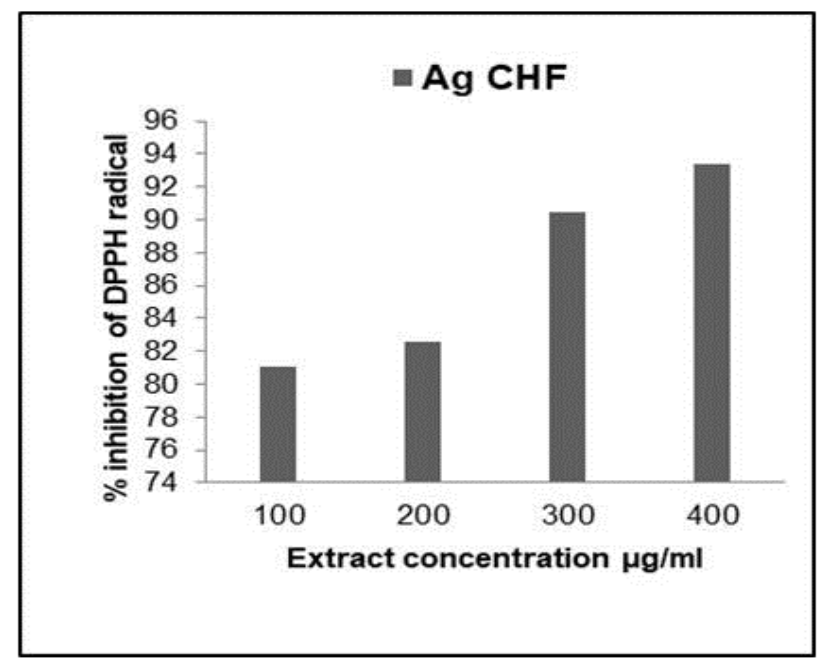

Figure 4: \% Inhibition of DPPH free radicals by $A$. glauca chloroform extract (Ag CHF).

antioxidant ability of methanolic extract was significantly lower than rutin and ascorbic acid, while it was higher than BHA. $\mathrm{IC}_{50}$ value of $\mathrm{MeOH}$ extract $(69.42 \mu \mathrm{g}$ / $\mathrm{ml})$ was half of the BHA $(157.63 \mu \mathrm{g} / \mathrm{ml})$, while it was significantly higher than the $\mathrm{IC}_{50}$ s of rutin $(45.19 \mu \mathrm{g} / \mathrm{ml})$ and ascorbic acid $(21.43 \mu \mathrm{g} / \mathrm{ml})$ (Figure 7$)$.

The results showed that highest anti-oxidant potential was present in $\mathrm{MeOH}$ extract followed by $\mathrm{CHF}$, aqueous and PET. Phytochemical analysis of the different extracts showed that flavonoids, terpenoids and tannins, which are strong anti-oxidants were present in $\mathrm{MeOH}$ extract only. The remaining three extracts were either devoid of (aqueous) or were having only one of these phytochemicals (PET and CHF). Joshi et al. ${ }^{56}$ reported 


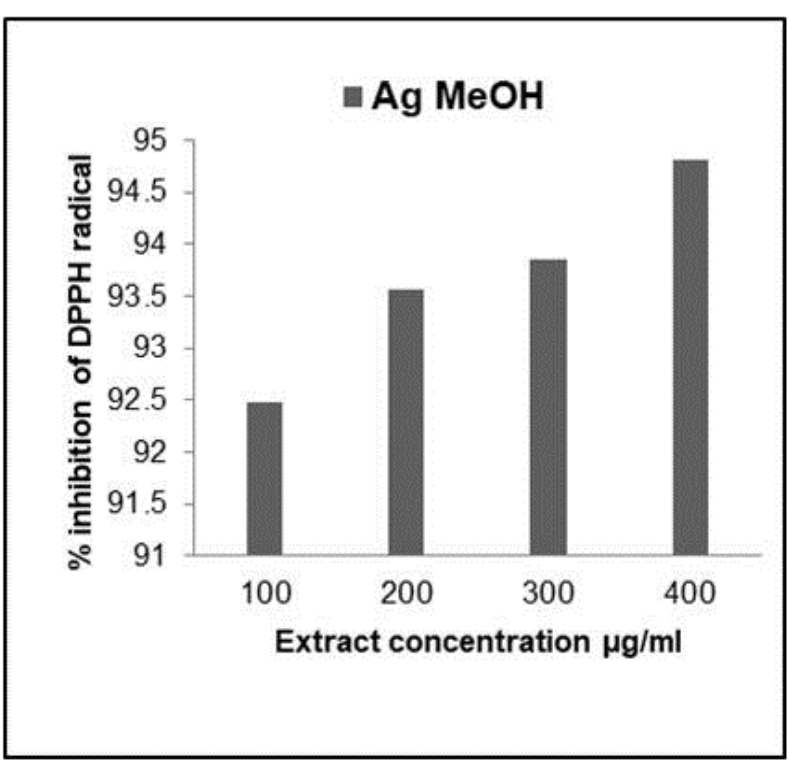

Figure 5: \% Inhibition of DPPH free radicals by A. glauca methanol extract (Ag $\mathrm{MeOH})$.

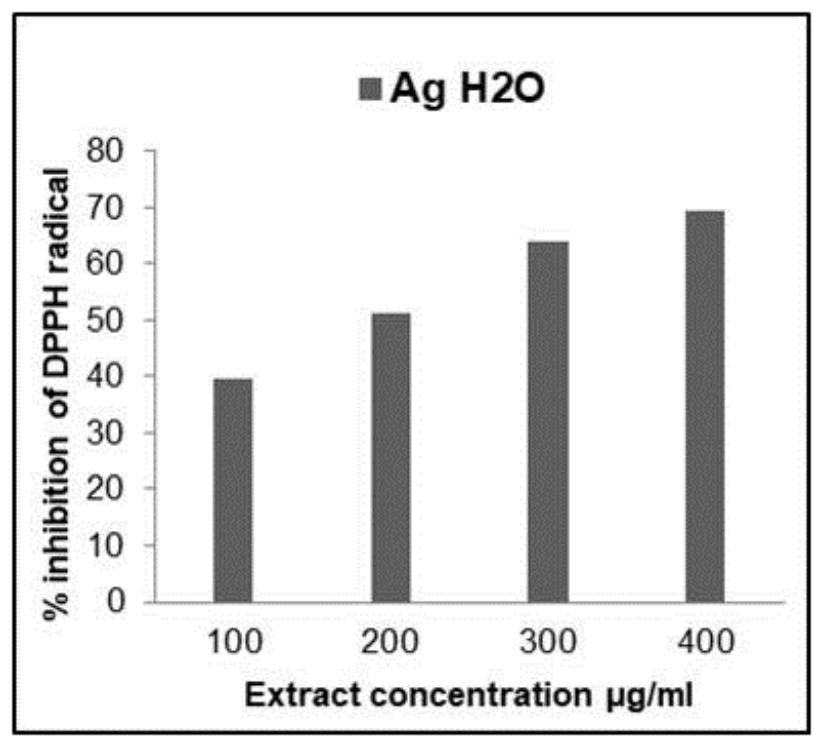

Figure 6: \% Inhibition of DPPH free radicals by $A$. glauca aqueous extract $\left(\mathrm{Ag} \mathrm{H}_{2} \mathrm{O}\right)$.

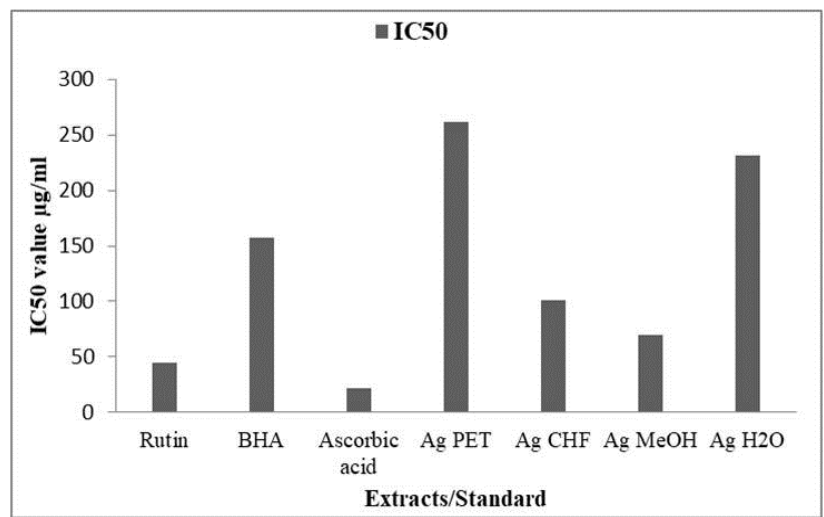

Figure 7: Comparison of the DPPH free radicals scavenging ability by various extracts of $A$. glauca with standard antioxidant. BHA= Butylated Hydroxyl Anisole, Ag PET= Petroleum ether extract of $A$. glauca, $\mathrm{Ag} \mathrm{CHF}=\mathrm{Chloroform}$ extract of $A$. glauca, $\mathrm{Ag} \mathrm{MeOH}=$ Methanolic extract of $A$. glauca and $\mathrm{Ag} \mathrm{H}_{2} \mathrm{O}=$ Aqueous extract of A. glauca.

antioxidant activity of water extract of $A$. glauca, the scavenging activity of the water extract ranged from $14.58 \%$ to $71.53 \%$ when amount of extract increased from 5 to $25 \mathrm{mg}$, which was much lower compared to the antioxidant activities of aqueous extract of $A$. glauca reported by us. In present study 100 to $400 \mu \mathrm{g}$ of extract showed $50.94 \%$ to $69.36 \%$ inhibition of $\mathrm{DPPH}$, this could be due to different in extract preparation methods, in which we don't dried the extract at $50^{\circ} \mathrm{C}$ under vaccum, which may cause degradation of phytochemicals. Irshad et al. ${ }^{26}$ reported that the essential oil of $A$. glauca exhibited good DPPH radical scavenging activity showing (93.4\% of inhibition and $45.05 \%$ inhibition of peroxidation). In present study the PET extract also showed similar range of antioxidant activity.

\section{Phytochemical analysis of A. glauca root and stem extracts}

List of different phytochemicals present in the 'root and stem' extracts of A. glauca are shown in Table 2. Studies prior to this work analyzed the phytochemical

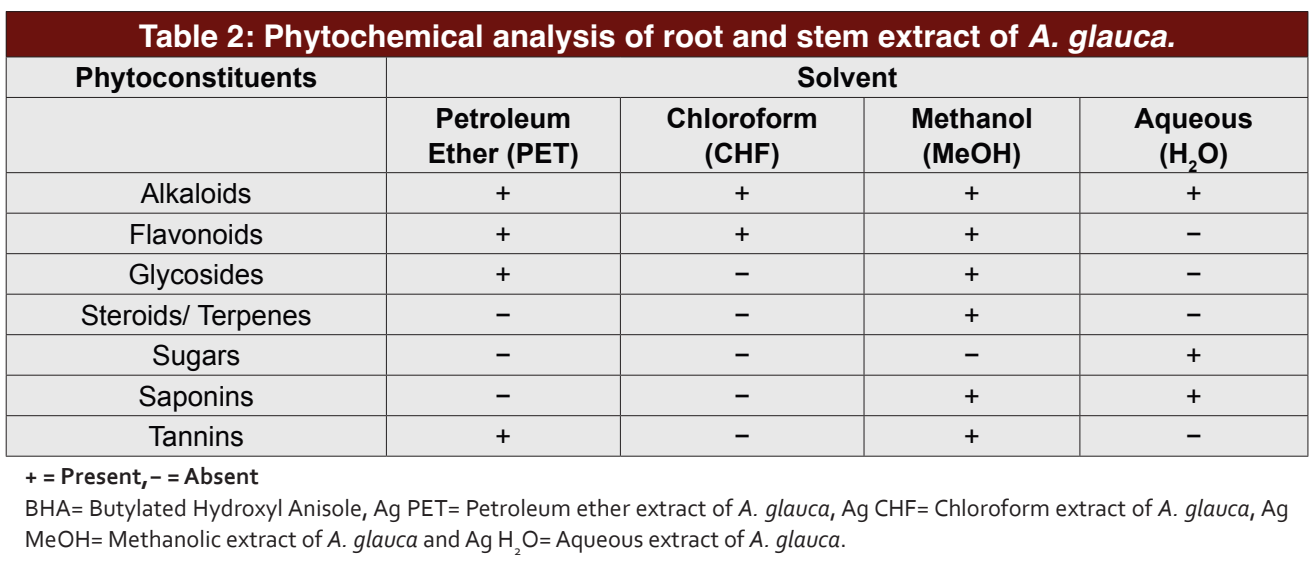


composition of essential oil of root and aerial part of A. glauca, which would be equivalent to petroleum ether or hexane extract of the plant. Alkaloids, Flavonoids, Glycosides, Steroids, Terpenes, Sugars, Saponins and Tannins were present in aqueous and $\mathrm{MeOH}$ extract of A. glauca. Water and methanol are polar solvents and as expected polar compounds like sugar and saponins were present in it. CHF extract was found to contain only alkaloids and flavonoids, while alkaloids, flavonoids, glycosides and tannins were present in PET extract. Due to diverse compositions of alkaloids, flavonoids and tannins, these compounds were present in both polar (water and $\mathrm{MeOH}$ ) and non-polar (PET) extracts. All these groups of compounds possess potent medicinal properties, and the antimicrobial potential of $A$. glauca is considered due to these chemicals.

Those primary and secondary metabolites present in $A$. glauca may be responsible for its antibacterial properties against tested micro-organisms, because the earlier pharmacology studies have publicized the role of $A$. glauca based herbal remedies in treatment of common respiratory problems like common cold, asthma, and cough. GC-MS analysis revealed the presence of 34 phytochemicals including Citronellol, Limonene, alpha and beta Pinene, alpha and beta Phellandrene, Thujene, Terpinene, Cis and trans-Ocimene, Germacrene D, b-Bisabolene, Alloaromadendrene, Piperitol, transCarveol and Carvone from the essential oil obtained from aerial parts of $A$. glauca. ${ }^{23}$ Two compounds ligustilide and butylidene phthalides were specifically present in essential oil from root of $A$. glauca, while 16 monoterpenoids were common in both the oils. ${ }^{57}$

Flavonoids and terpenoids possess strong antioxidant activity and also show in-vitro antimicrobial activity. The possible mode of action of flavonoids is complex formation with soluble and extracellular proteins and inducing perturbations in cell wall of bacteria. ${ }^{58}$ Saponins also affect the permeability of membrane owe to their detergent like actions. Due to presence of phenolic groups tannins also possess antibacterial activities. Tannins suppress bacterial multiplication by blocking essential metabolic enzymes required for normal growth. Presence of these phytochemicals in $A$. glauca can account for its antimicrobial and antioxidant activities. ${ }^{59}$

Although there are many reports on use the usage of A. glauca as local medicine and its antibacterial activities, but the available herbal formulations in the Indian market don't have this component. Even the famous Indian bioactive health supplement and immunity booster 'Chyawanprash' also lacks $A$. glauca. ${ }^{60}$ The reason for this could be the very low availability of this herb to be used at commercial scale. The 'High Altitude Plant Physiology Research Center (HAPPRC) of H. N. B. Garhwal University, Srinagar Garhwal is engaged in in-situ cultivation at higher altitudes so that it could be made available in larger quantities.

Further investigations on phytochemical composition, followed by isolation of pure compound may provide some new antibacterial agent from $A$. glauca. Presence of AMPs is also reported from $A$. glauca and further investigation could provide new AMPs form $A$. glauca.

\section{CONCLUSION}

In this study, methanol extract of root and stem of $A$. glauca have demonstrated strong antibacterial activity against the selected pathogenic bacteria of respiratory tract which may be due to the presence of major phytochemicals present in it. Furthermore, the results suggest a strong likelihood of developing safe effective and cheap antibacterial agent from various parts of $A$. glauca. The methanolic fraction of $A$. glauca can also be used as a new source of natural strong antioxidants. The future aspects of this study include isolating and identifying pure active compounds which are responsible for antibacterial action. The conclusion specifies that scientific studies performed on medicinal plants that have conventional efficacy may warrant fruitful results. Root and stem of $A$. glauca could be powerful source of novel antibiotics and major antioxidant compounds.

\section{ACKNOWLEDGEMENT}

The PA is thankful to U.G.C., New Delhi and H. N. B. Garhwal University (A Central University) Srinagar (Garhwal), for financial support during his Ph.D. degree. All the authors are thankful to the University and Department of Botany and Microbiology, HNBGU for providing necessary workspace and laboratory facilities.

\section{CONFLICT OF INTEREST}

The authors declare that they have no conflict of interest.

\section{ABBREVIATIONS}

\%: Percentage; $\mu \mathrm{g}$ : Microgram; $\mathrm{ml}$ : Millilitre; $\boldsymbol{\mu l}$ Microliter; mm: Millimetre; mg: Milligram; g: Gram; ${ }^{\circ} \mathrm{C}$ : Degree Celsius; hrs: Hours; PET: Petroleum Ether; CHF: Chloroform; MIC: Mininum Inhibitory Concentration; $\mathbf{M e O H}$ : Methanol; DMSO: Dimethyl Sulphoxide. 


\section{REFERENCES}

1. Bhavnani SM, Ballow $\mathrm{CH}$. New agents for gram-positive bacteria. Current Opinion of Microbiology. 2000;3(5):528-34

2. Chariandy $\mathrm{CM}$, Seaforth $\mathrm{CE}$, Phelps RH, Pollard GV, Khambay BPS. Screening of medicinal plants from Trinidad and Tobago for antimicrobial and insecticidal properties. Journal of Ethnopharmacology. 1999;64(3):265-70.

3. Bankole MA, Shittu LAJ, Ahmed TA, Bankole MN, Shittu RK, Terkula K, et al. Synergistic antimicrobial activities of phytoestrogens in crude extracts of two sesame species against some common pathogenic microorganisms. African Journal of Traditional, Complementary and Alternative Medicines. 2007;4(4):427-33.

4. Martindale W. Martindale: The extra pharmacopoeia, $31^{\text {st }}$ edition edn. London: Royal Pharmaceutical Society; 1996.

5. Lis-Balchin M, Deans SG. Bioactivity of selected plant essential oils against Listeria monocytogenes. Journal of Applied Microbiology. 1997;82(6):759-62.

6. Rios JL, Recio MC. Medicinal plants and antimicrobial activity. Journal of Ethnopharmacology. 2005;100(1-2):80-4.

7. Kambu K, Phanzu ND, Coune C, Wauters JN, Angenot L. Contribution à l'étude des propriétés insecticides et chimiques d'Eucalyptus saligna du Zaïre. Plantes Médicinales et Phytothérapie. 1982;16(1):34-8

8. Said-Al Ahl HA, Hikal WM, Tkachenko KG. Essential oils with potential as insecticidal agents: A review. Int J Environ Plan Manag. 2017;34:23-33.

9. Harbottle H, Thakur S, Zhao S, White DG. Genetics of Antimicrobial Resistance. Animal Biotechnology. 2006;17(2):111-24.

10. Cardoso TC, Lopes IM, Carneiro AH. A case-control study on risk factors for early-onset respiratory tract infection in patients admitted in ICU. BMC Pulmonary Medicine. 2007;7(1):12.

11. Subbarao K, Mahanty S. Respiratory virus infections: Understanding COVID-19. Immunity. 2020;52(6):905-9.

12. Ibrahim EH, Ward S, Sherman G, Kollef MH. A comparative analysis of patients with early-onset vs late-onset nosocomial pneumonia in the ICU setting. Chest. 2000;117(5):1434-42.

13. Alagumuthu M, Arumugam S. Molecular docking, discovery, synthesis, and pharmacological properties of new 6-substituted-2-(3-phenoxyphenyl)4-phenyl quinoline derivatives; an approach to developing potent DNA gyrase inhibitors/antibacterial agents. Bioorganic and Medicinal Chemistry. 2017;25(4):1448-55.

14. Gautam SS, Kumar S. The antibacterial and phytochemical aspects of Viola odorata Linn. Extracts against respiratory tract pathogens. Proceedings of the National Academy of Sciences, India Section B: Biological Sciences. 2012;82(4):567-72.

15. Bai S, Bharti P, Seasotiya L, Malik A, Dalal S. In vitro screening and evaluation of some Indian medicinal plants for their potential to inhibit Jack bean and bacterial ureases causing urinary infections. Pharmaceutical Biology. 2014;53(3):326-33.

16. Abboud Y, Saffaj T, Chagraoui A, ElBouari A, Brouzi K, Tanane O, et al. Biosynthesis, characterization and antimicrobial activity of copper oxide nanoparticles (CONPs) produced using brown alga extract (Bifurcaria bifurcata). Applied Nanoscience. 2014;4(5):571-6.

17. Raut SV, Pingle YA. Screening and characterization of antimicrobial substances produced by Bacillus species. Journal of Pure and Applied Microbiology. 2010;4(1):321-31.

18. Jayapriya J, Ramamurthy V. Use of non-native phenazines to improve the performance of Pseudomonas aeruginosa MTCC 2474 catalysed fuel cells. Bioresource Technology. 2012;124:23-8.

19. Pimenov MG, Leonov MV. The Asian Umbelliferae biodiversity database (ASIUM) with particular reference to South-West Asian taxa. Turkish Journal of Botany. 2004;28(1-2):139-45.

20. Samant SS, Dhar U, Palni LMS. Medicinal Plants of Indian Himalaya: Diversity, Distribution Potential Values. Nainatal: Gyanodaya Prakashan; 1998.

21. Butola JS, Badola HK. Effect of pre-sowing treatment on seed germination and seedling vigour in Angelica glauca, a threatened medicinal herb. Current Science. 2004;796-9.

22. Gaur RD. Flora of the District Garhwal, North West Himalaya Transmedia; 1999.
23. Agnihotri VK, Thappa RK, Meena B, Kapahi BK, Saxena RK, Qazi GN, et al. Essential oil composition of aerial parts of Angelica glauca growing wild in North-West Himalaya (India). Phytochemistry. 2004;65(16):2411-3.

24. Collett H. Flora Simlensis: A handbook of the flowering plants of Shimla and the neighbourhood. Calcutta and Shimla: Thacker Spink and Company; 1921.

25. Irshad M, Aziz S, Habib UR, Hussain H. GC-MS Analysis and Antifungal Activity of Essential oils of Angelica glauca, Plectranthus rugosus, and Valeriana wallichii. Journal of Essential Oil Bearing Plants. 2012;15(1):15-21.

26. Irshad M, Shahid M, Aziz S, Ghous T. Antioxidant, antimicrobial and phytotoxic activities of essential oil of Angelica glauca. Asian Journal of Chemistry. 2011;23(5):1947.

27. Purohit VK, Andola HC, Haider SZ, Tiwari D, Bahuguna YM, Gairola KC, et al. Essential oil constituents of Angelica glauca Edgew. Roots: An endangered species from Uttarakhand Himalaya (India). National Academy Science Letters. 2015;38(5):445-7.

28. Sowndhararajan K, Deepa P, Kim M, Park SJ, Kim S. A review of the composition of the essential oils and biological activities of Angelica species. Scientia Pharmaceutica. 2017;85(3):33.

29. Fraternale D, Flamini G, Ricci D. Essential oil composition and antimicrobia activity of Angelica archangelica L.(Apiaceae) roots. Journal of Medicinal Food. 2014;17(9):1043-7.

30. Mullen KAE, Lee AR, Lyman RL, Mason SE, Washburn SP, Anderson KL. An in vitro assessment of the antibacterial activity of plant-derived oils. Journal of Dairy Science. 2014;97(9):5587-91.

31. Prakash B, Singh P, Goni R, Raina AKP, Dubey NK. Efficacy of Angelica archangelica essential oil, phenyl ethyl alcohol and $\hat{I} \pm$-terpineol against isolated molds from walnut and their antiaflatoxigenic and antioxidant activity. Journal of Food Science and Technology. 2014;52(4):2220-8.

32. Sharma S, Rasal VP, Patil PA, Joshi RK. Effect of Angelica glauca essential oil on allergic airway changes induced by histamine and ovalbumin in experimental animals. Indian Journal of Pharmacology. 2017;49(1):55.

33. Negi A, Maurya VK. Antibacterial potential of Antimicrobial peptides containing whole proteins of two Adiantum species from Himalaya against selected human bacterial pathogens. International Journal of Research in Pharmaceutical Sciences. 2020;11:2603-13.

34. Ahmad I, Mehmood Z, Mohammad F. Screening of some Indian medicinal plants for their antimicrobial properties. Journal of Ethnopharmacology. 1998;62(2):183-93.

35. Chandra H, Srivastava J, Agarwal RK. Fundamental Techniques in Microbiology Publisher John Publisher Pvt. Ltd, New Delhi; 2016.

36. Schwalbe R, Steele-Moore L, Goodwin AC. Antimicrobial susceptibility testing protocols CRC Press; 2007.

37. Clarke EGC. Clarke's Isolation and Identification of Drugs in Pharmaceuticals, Body Fluids and Post-mortem Material, 2 ${ }^{\text {nd }}$ Edition edn. London: The Pharmaceutical Press; 1986.

38. Gul R, Jan SU, Faridullah S, Sherani S, Jahan N. Preliminary phytochemical screening, quantitative analysis of alkaloids, and antioxidant activity of crude plant extracts from Ephedra intermedia indigenous to Balochistan. The Scientific World Journal. 2017.

39. Hossain MA, Al-Raqmi KAS, Al-Mijizy ZH, Weli AM, Al-Riyami Q. Study of total phenol, flavonoids contents and phytochemical screening of various leaves crude extracts of locally grown Thymus vulgaris. Asian Pacific Journal of Tropical Biomedicine. 2013;3(9):705-10

40. Evans WC, Trease GE. Trease and Evans' pharmacognosy, 13 edn Philadelphia, London: Baillière Tindall; 1989.

41. Maria R, Shirley M, Xavier C, Jaime S, David V, Rosa S, et al. Preliminary phytochemical screening, total phenolic content and antibacterial activity of thirteen native species from Guayas province Ecuador. Journal of King Saud University-Science. 2018;30(4):500-5.

42. Hikino $\mathrm{H}$, Kiso $\mathrm{Y}$, Wagner $\mathrm{H}$, Fiebig M. Antihepatotoxic actions of flavonolignans from Silybum marianum fruits. Planta Medica. 1984;50(03):248-50.

43. Nath MC, Chakravorty MK, Chowdhury SR. Liebermann-Burchard reaction for steroids. Nature. 1946;157(3978):103-4.

44. Arthur HR, Chan PKR. A survey of Hong Kong plants testing for Alkaloids, essential oils and saponins. Trop Sci. 1962;4:147.

45. Sheng ZW, Ma WH, Gao JH, Bi Y, Zhang WM, Dou HT, et al. Antioxidant properties of banana flower of two cultivars in China using 2, 2-diphenyl-1picrylhydrazyl (DPPH,) reducing power, 2, 2'-azinobis-(3-ethylbenzthiazoline- 
6-sulphonate (ABTS) and inhibition of lipid peroxidation assays. African Journal of Biotechnology. 2011;10(21):4470-7.

46. Fraternale D, Flamini G, Ricci D. Essential oil composition of Angelica archangelica L. (Apiaceae) roots and its antifungal activity against plant pathogenic fungi. Plant Biosystems: An International Journal Dealing with all Aspects of Plant Biology. 2016;150(3):558-63.

47. Roh J, Shin S. Antifungal and antioxidant activities of the essential oil from Angelica koreana Nakai. Evidence-Based Complementary and Alternative Medicine. 2014.

48. Tabanca N, Gao Z, Demirci B, Techen N, Wedge DE, Ali A, et al. Molecular and phytochemical investigation of Angelica dahurica and Angelica pubescentis essential oils and their biological activity against Aedes aegypti, Stephanitis pyrioides, and Colletotrichum species. Journal of Agricultural and Food Chemistry. 2014;62(35):8848-57.

49. Chopra RN, Nayar SL, Chopra IC. Glossary of Indian medicinal plants Council of Scientific and Industrial Research New Delhi; 1956.

50. Han C, Guo J. Antibacterial and anti-inflammatory activity of traditional Chinese herb pairs, Angelica sinensis and Sophora flavescens. Inflammation. 2012;35(3):913-9.

51. Cunningham MW. Pathogenesis of group A streptococcal infections. Clinical Microbiology Reviews. 2000;13(3):470-511.
52. Henriques-Normark B, Tuomanen El. The pneumococcus: Epidemiology, microbiology, and pathogenesis. Cold Spring Harbor Perspectives in Medicine. 2013;3(7):a010215.

53. Li B, Zhao Y, Liu C, Chen Z, Zhou D. Molecular pathogenesis of Klebsiella pneumoniae. Future Microbiology. 2014;9(9):1071-81.

54. Kobayashi SD, Malachowa N, DeLeo FR. Pathogenesis of Staphylococcus aureus abscesses. The American Journal of Pathology. 2015;185(6):1518-27.

55. Azam MW, Khan AU. Updates on the pathogenicity status of Pseudomonas aeruginosa. Drug Discovery Today. 2019;24(1):350-9.

56. Joshi S, Prakash O, Hore SK, Zafar A, Pant AK. Hepatoprotective and antioxidant activity of the aqueous extract of Angelica glauca Edgew. root. Asian Journal of Traditional Medicines. 2008;3(2):58-66.

57. Thappa RK, Kaul P, Chisti AM, Kapahi BK, Suri OP, Agarwal SG. Variability in the essential oil of Angelica glauca Edgew of different geographical regions. Journal of Essential Oil Research. 2005;17(4):361-3.

58. Moyo B, Masika PJ, Muchenje V. Antimicrobial activities of Moringa oleifera Lam leaf extracts. African Journal of Biotechnology. 2012;11(11):2797-802.

59. Godstime OC, Felix EO, Augustina JO, Christopher EO. Mechanisms of antimicrobial actions of phytochemicals against enteric pathogens: A review. J Pharm Chem Biol Sci. 2014;2(2):77-85.

60. Sharma R, Martins NI, Kuca K, Chaudhary A, Kabra A, Rao MM, et al. Chyawanprash: A traditional Indian bioactive health supplement. Biomolecules 2019;9(5):161.

\section{PICTORIAL ABSTRACT}

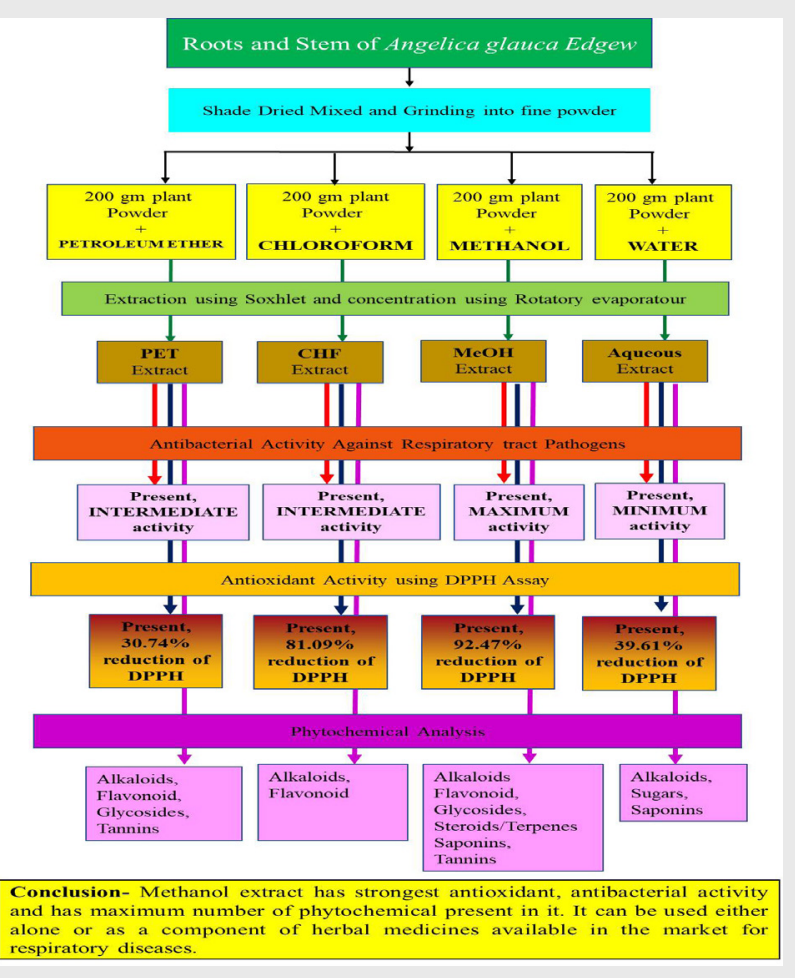

\section{SUMMARY}

In the present study the 'root and stem' of Angelica glauca (Choru) were analyzed for their anti-bacterial, anti-oxidant potential and for the presence of bioactive phytochemicals in it. The PET, CHF, $\mathrm{MeOH}$ and $\mathrm{H}_{2} \mathrm{O}$ extracts of 'root and stem' of $A$. glauca were prepared. The study confirmed good anti-bacterial activity of the plant extracts against the selected bacterial pathogens (Staphylococcus aureus, Streptococcus pneumonia, Streptococcus pyogenes, Pseudomonas aeruginosa and Klebsiella pneumonia) causing infections in human respiratory tract. $\mathrm{MeOH}$ extract showed the most potent anti-bacterial activity and maximum types of phytochemicals (Alkaloid, flavonoids, terpenes, tannins, saponins and glycosides) were present in it. Plant also showed good anti-oxidant activity using DPPH assay. Since the bacteria used in the study cause respiratory infections, and the plant showed good anti-oxidant activities, the use of $A$. glauca, either in pure form or in combination with other herbs, may be suggested in the marketed herbal formulations for respiratory diseases. This study was preliminary investigation on the phytochemical constituents of $A$. glauca, further studies on isolation, purification and other biological activities of this plants are awaited. 


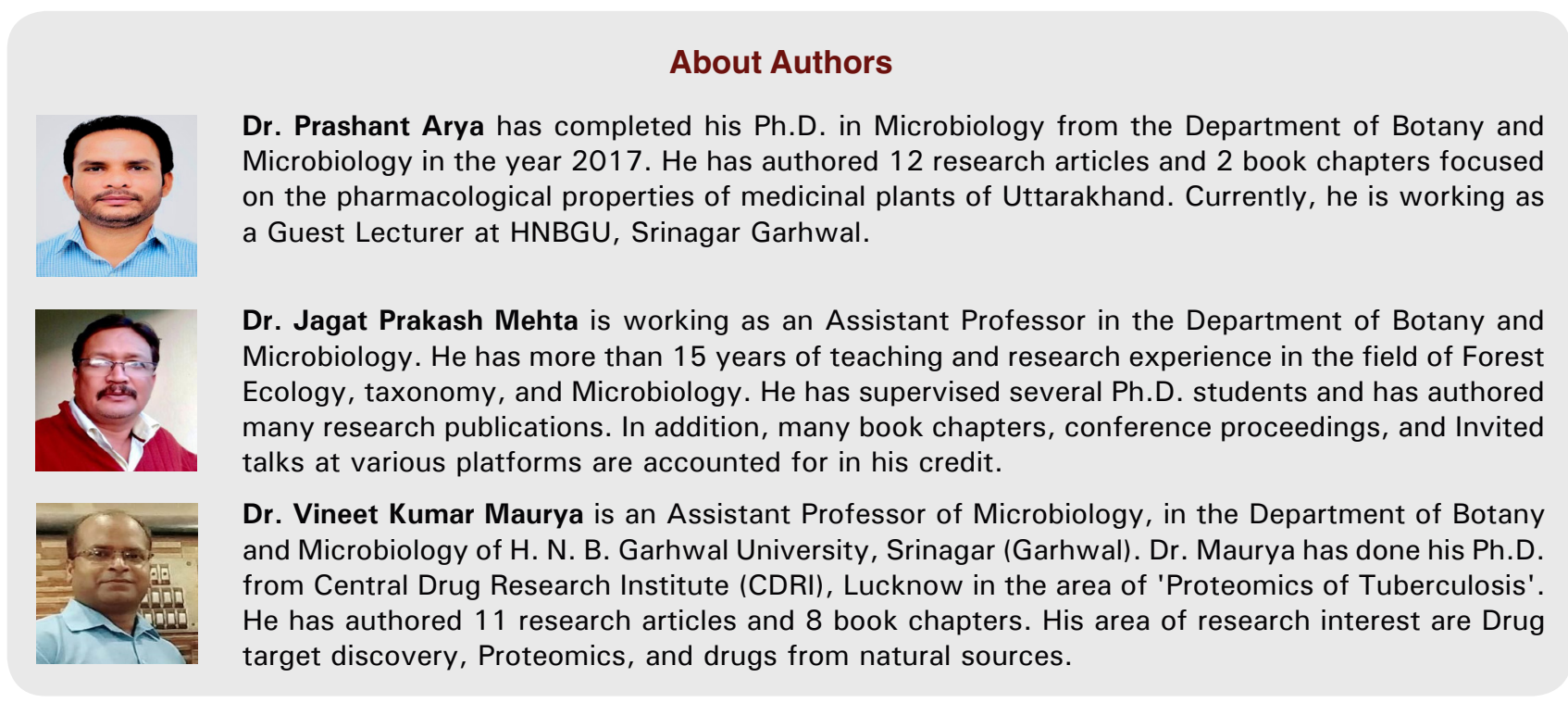

Cite this article: Arya P, Mehta JP, Maurya VK. Methanolic Extract of Angelica glauca Edgew Root and Stem: A Possible Component of Herbal Medicines against Respiratory Infections. Indian J of Pharmaceutical Education and Research. 2021;55(2s):s552-s562. 